\title{
Microstructures upon explosion welding and processes which prevent joining of materials
}

\author{
B. A. Greenberg', , M. A. Ivanov², S. V. Kuzmin², V.I. Lysak³, Y.P. Besshaposhnikov, \\ M. S. Pushkin ${ }^{1}$, A. V. Inozemtsev ${ }^{1}$, A. M. Patselov ${ }^{1}$ \\ †bella@imp.uran.ru
}

\begin{abstract}
${ }^{1}$ M.N. Miheev Institute of Metal Physics, Ural Branch of RAS, 18 S. Kovalevskaya str., Yekaterinburg, 620990, Russia ${ }^{2}$ Kurdyumov Institute of Metal Physics, National Academy of Sciences of Ukraine, 36 Vernadskogo blvd., Kiev, 03680, Ukraine ${ }^{3}$ Volgograd State Technical University, 28 Lenin Av., Volgograd, 400005, Russia ${ }^{4}$ OJSC Ural Chemical Engineering Plant, 33 Khibinogorskii lane, Yekaterinburg, 620010, Russia
\end{abstract}

The present paper examines features of interface structure and analyzes possible risk zones for two to a certain degree alternative objects manufactured from composites produced by explosive welding. One of those is a chemical reactor vessel; the other is a petrochemical reactor vessel (a coke drum). The engineering of a chemical reactor vessel is an example of a successful implementation of explosive welding. The analysis of the chemical reactor wall structure containing a coppertantalum welded joint revealed the reasons for its stability that provides reactor's extended service life in a harsh environment. However, a risk zone can emerge due to the quasi-wave nature of the interface. On the contrary, factors that shorten the service life were found for the petrochemical reactor. The contact zone of the plates for the shell of the petrochemical reactor (the coke drum) produced by explosive welding and made of $08 \mathrm{Cr} 13$ and $12 \mathrm{CrMo}$ steel consists of five layers. The segregation of carbon provokes the eutectoid decomposition that causes formation of colonies of rod-shaped carbides. As a result, two risk zones can be observed: the melted zone and the segregation zone. Using the copper-titanium joints as examples, the effect of intermetallic reactions on the strength of a welded joint was studied. Disordered and unfaceted clusters were observed to turn into intermetallic particles and then into agglomerates. Attention is drawn to the fact that the variety of operating modes and conditions makes the formation of intermetallic compound really hazardous.

Keywords: explosive welding, chemical reactor, petrochemical reactor (coke drum), mutual solubility, interface, melted zone, intermetallic formation.

УДК: 621.791 .13

\section{Микроструктуры, препятствующие сцеплению материалов при сварке взрывом}

\author{
Гринберг Б. А. ${ }^{1 \dagger}$, Иванов М. А. ${ }^{2}$, Кузьмин С. В. ${ }^{3}$, Лысак В. И. ${ }^{3}$, Бесшапошников Ю. П. ${ }^{4}$, \\ Пушкин М. С. ${ }^{1}$, Иноземцев А. В. ${ }^{1}$, Пацелов А. М. ${ }^{1}$ \\ ${ }^{1}$ Институт физики металлов имени М.Н. Михеева УрО РАН, ул. С. Ковалевской, 18, Екатеринбург, 620990, Россия \\ ${ }^{2}$ Институт металлофизики им. Г. В. Курдюмова, НАН Украины, бульв. акад. Вернадского, 36, Киев, 03142, Украина \\ ${ }^{3}$ Волгоградский государственный технический университет, пр. Ленина, 28, Волгоград, 400005, Россия \\ ${ }^{4} \mathrm{OAO} \mathrm{“Уралхиммаш”,} \mathrm{ул.} \mathrm{Хибиногорская,} \mathrm{33,} \mathrm{Екатеринбург,} \mathrm{620010,} \mathrm{Россия}$
}

Рассмотрены особенности структуры поверхности раздела и проанализированы возможные зоны риска для двух, в известной степени, альтернативных объектов, получаемых сваркой взрывом. Один из них - химический реактор, другой - нефтехимический реактор (коксовая камера). Конструирование стенки химического реактора является примером успешной реализации сварки взрывом. В результате анализа структуры стенки химического реактора, содержащей сварное соединение медь-тантал, выявлены причины ее стабильности, обеспечивающие длительное время эксплуатации реактора в условиях агрессивных сред. Однако зона риска может возникать благодаря квазиволновой природе поверхности раздела. Напротив, для нефтехимического реактора выявлены причины, уменьшающие время его использования. Зона контакта двух пластин для стенки нефтехимического реактора (коксовой камеры), сделанных путем сварки взрывом из стали 08Cr13 и стали 12CrMo, состоит из пяти слоев. Сегрегация углерода 
стимулирует эвтектоидный распад, который вызывает образование колоний стержневидных карбидов. В результате наблюдаются две зоны риска: расплавленная зона и зона сегрегации. Стенки реактора испытывают давление в результате смешивания тяжелых фракций нефти. На примере соединения медь-титан изучено влияние интерметаллических реакций на прочность сварных соединений. Наблюдались разупорядоченные и неограненные кластеры и их превращения в интерметаллические частицы, которые затем превращались в агломераты. Обращается внимание на тот факт, что многообразие действующих способов и условий делает опасность образования интерметаллидов вполне реальной.

Ключевые слова: сварка взрывом, химический реактор, нефтехимический реактор (коксовая камера), взаимная растворимость, границы раздела, расплавленная зона, образование интерметаллидов.

\section{Introduction}

The article is an authors' review that mainly includes authors' works and their theoretical discussion. Actually, this is a review based on the original results. The article notes certain approaches that used to be generally accepted but have been refuted as a result of the authors' original research. These are the requirements for atomistically smooth and clean surfaces, mutual solubility of original elements and the risk of intermetallics formation $[1,2,3]$. Throughout the article, certain conditions, under which the above factors result in emerging of risk zones, i.e., at the risk of losing the continuity of welded joints are analyzed.

Such typical aspects of explosive welding as fragmentation, heterogeneity formation on the interface and also melting and vortex formation [4] are described.

\section{Materials and methods}

The explosive welding was carried out at the Volgograd Technical University and the OJSC Ural Chemical Engineering Plant, Ekaterinburg. The process scheme generally accepted in this field was used [3]. Using these schemes, Cu-Ta, steel-steel (08Cr13-12CrMo) and $\mathrm{Cu}-\mathrm{Ti}$ joints reviewed in this paper were obtained.

Originally, vessel walls of a chemical reactor were made of the plates of the tantalum - copper - steel composite $1800 \mathrm{~mm} \times 300 \mathrm{~mm} \times 55 \mathrm{~mm}$ in size [5]. Our laboratory samples, unlike the original, did not contain the steel layer. Instead, we used samples obtained by welding of tantalum and copper sheets. It is the strength of this composite that enables one to use the high corrosion resistance of tantalum and, accordingly, to operate the reactor for a long period of time.

The initial samples for welding had the following thicknesses: tantalum $-0.1 \mathrm{~mm}$, copper $-3.5 \mathrm{~mm}$. The lengths and widths of the laboratory samples were in the range of dozens of millimeters. Here, we would like to focus on the main welding parameters which were applied to obtain the copper-tantalum joint: impact angle $\gamma=11.8^{\circ}$, contact point velocity $V_{c}=2125 \mathrm{~m} / \mathrm{s}$. These are based on the fact that common reasons exist for the copper-tantalum joints and composites used in large-sized industrial objects for them to have a high quality and stability.

The coke drum shell was made of two-layer steel $08 \mathrm{Cr} 13$ - steel $12 \mathrm{CrMo}$ composite produced by means of explosive welding. Stainless steel $08 \mathrm{Cr} 13$, with the chemical composition (wt.\%) $0.08 \mathrm{C}, 0.40 \mathrm{Si}, 0.80 \mathrm{Mn}, 0.60 \mathrm{Ni}, 13.0 \mathrm{Cr}$ and balance Fe was used for the inner layer of the drum wall; and low carbon steel $12 \mathrm{CrMo}$, with the chemical composition (wt.\%) $0.12 \mathrm{C}, 0.30 \mathrm{Si}, 0.70 \mathrm{Mn}, 1.0 \mathrm{Mo}, 1.0 \mathrm{Cr}$ and balance Fe was used for the outer layer. Plates produced by explosive welding were $4-5 \mathrm{~m}$ long and maximum $2.4 \mathrm{~m}$ wide. The thickness of the base plate was $24 \mathrm{~mm}$, while for the flyer plate it was $6 \mathrm{~mm}$. The contact point velocity was $2400-2700$ $\mathrm{m} / \mathrm{s}$. The impact angle of the plates was $9-11^{\circ}$. After the welding, tempering was applied to release residual stresses at $680-700^{\circ} \mathrm{C}$ for approximately 2 hours.

Formation of intermetallics during the explosive welding of different materials was studied for various welding modes.

The shear strength tests were performed on a universal FP-100 tensile testing machine in accordance with the recommendation of GOST 10885 - 85 .

The metallographic analysis was performed using the optical microscope Epiquant equipped with the SIAMS computational system. The studies of the microstructure were performed using the transmission electron microscopes JEM 200CX and CM-30 Super Twin, scanning electron microscopes Quanta 200 3D and Quanta 600 (with the maximum resolution of about $2 \mathrm{~nm}$ ). The foil samples were prepared using the ion gun Fashione 1010 ION MILL.

\section{Results and discussion}

\subsection{Chemical Reactor}

The chemical reactor vessel is made by Dynamic Materials Corporation (USA) and reported about in [5]. The reactor's length is $12.6 \mathrm{~m}$, its diameter is $2.1 \mathrm{~m}$ and the wall thickness is $50 \mathrm{~mm}$. The internal surface is made up of tantalum the layer thickness of which is $1 \mathrm{~mm}$. Such a design of the vessel is based on the high corrosion resistance of tantalum, which, on the other hand, is an expensive material. In spite of the fact, however, explosive welding is used to build such a large vessel with its internal surface lined with tantalum. The external wall of the vessel is made of carbon steel. As per the data presented in [5], both internal interfaces of the composite are wavelike. Using the copper-tantalum weld joint, the reason for mixing of immiscible suspensions upon explosion welding was elucidated in [6]. Other results of the copper-tantalum weld joint structure examination are provided in [7].

In the case of a wavy interface, the longitudinal section of the composite presents a set of alternating bands of copper and tantalum with parallel interfaces (Fig. 1). The twodimensional image in Fig. 1a exhibits numerous asperities and local melted zones (of white color, different from the band color). A local melted zone of a vortex structure can be clearly seen in Fig. $1 \mathrm{~b}$ at a greater magnification. 
The observed asperities are those of tantalum, which is the more refractory metal of the two elements. The asperities are about a few dozens of microns in size. The roughness of the surfaces of the metal was measured before welding and it demonstrated that the size of the asperities after welding is by one or two orders of magnitude larger than the original surface roughness.

In Fig. 2 data are provided to explain the reasons for the high quality of the copper-tantalum joint. In Fig. 2a the aforementioned features of the interface, i.e. asperities and local melted zones, can be seen. In addition, smaller asperities of the next orders can be seen on some of the asperities. The formation of large asperities results in disintegration or merging of the bands. Nevertheless, the interface appears to be fairly regular. In Fig. $2 \mathrm{c}$ a big tantalum asperity has the size of approximately $100 \mu \mathrm{m}$. In the adjoining band a large local melted zone can be seen. Next to the asperity crest, marked with an arrow, a tantalum fragmentation into separate particles can be observed (Figs. 2d, e).

In Fig. $2 b$ a SEM image of the internal structure of a local melted zone is shown. Since copper and tantalum possess no mutual solubility, this zone is basically a colloidal solution of the suspension type as classified in [8]. The disperse phase is represented by the tantalum hard particles (that do not melt), while the dispersion medium is represented by the melted (and subsequently solidified) copper matrix.

Tantalum particles predominantly have the size of microns, but they can also be of a larger size as, for example, in Fig. 2c. Due to the dispersion hardening, the microhardness of the local melted zones is approximately $3000 \mathrm{MPa}$ that is close to the microhardness of tantalum and exceeds that of copper by $2000 \mathrm{MPa}$. Mechanical tests proved that the shear strength for the copper-tantalum joint is approximately $150-170 \mathrm{MPa}$ that exceeds the strength of copper.

In any case, the formation and flying-off of tantalum hard particles are similar to the flight of projectile fragments, and both of these are the result of explosion as it was described in [9]. The obstacles that will stop the fragments from flying out of one of the plates in explosive welding will be both the flyer plate and the initial base plate. With this, the flying-off of the hard particles will initiate the local melting of the more lowmelting material in the vicinity of the interface. The shape of the particles inside a local melted zone (Fig. 2b) is markedly different from that of the particles inside the fragmented layer (Figs. 2d, e): dispersed tantalum particles are markedly less indented than the particles that failed to fly-off.

For many materials, for example, polymers, the solution or melt of the same polymer are considered to be the best glues [10]. To some extent, this confirms the possibility of bonding metals in consideration due to their melting in explosive welding. Indeed, when melting the problems of wetting, adhesion, heat expansion and contact corrosion protection are solved.

Thus, explosive welding incorporates, to a certain degree, another way of joining materials, namely their bonding by means of formation of molten areas. It can be said that the present and our earlier studies have overcome the stereotype of the danger of melting in explosive welding. We have always observed certain local melted zones in the multiple

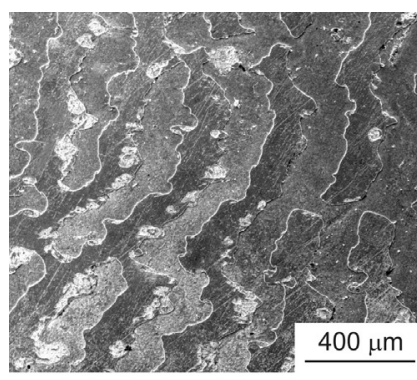

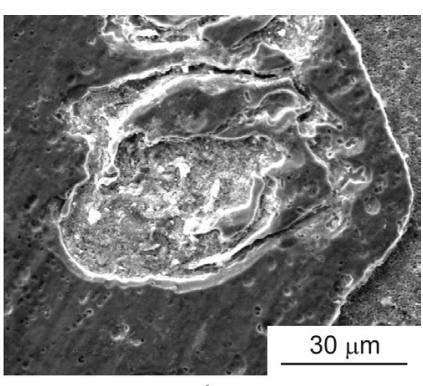

b
Fig. 1. Longitudinal section of the wavelike interface for the coppertantalum joint (SEM): copper and tantalum bands, local melted zones, asperities (a); local melted zone vortex structure (b).

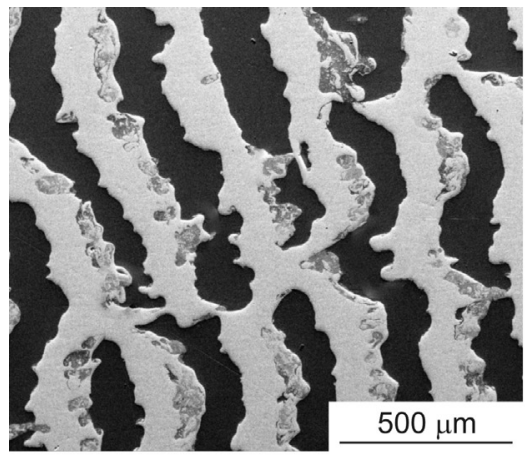

a

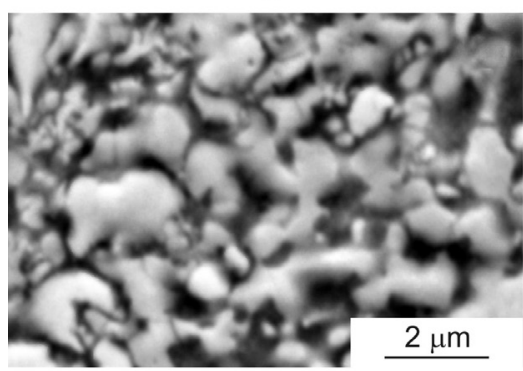

b
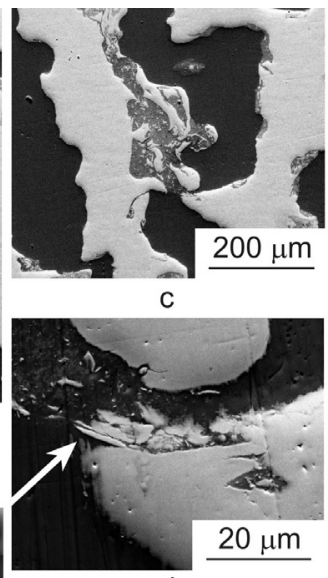

d

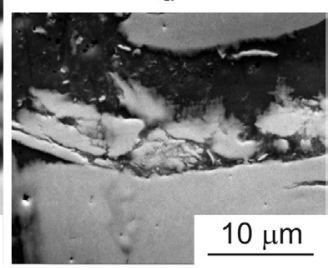

e

Fig. 2. Longitudinal section of the wavelike interface for the coppertantalum joint: copper and tantalum bands (a); tantalum particles in copper melt (b); tantalum asperity and local melted zone (c); fragmented layer at various magnifications $(d, e)$.

joints under study. They have a double function: dispersive solidification and spot gluing. Here are some of them: for example, Al-Ta, where the melted zone has the form of a molten (and then solid) film. But at the upper boundary of the weldability window (a set of welding parameters, the combination of which makes welding possible), the film grows so wide that when the return wave comes back, it does not have enough time to solidify, and no joint is obtained. In case of a petrochemical reactor, the local melted zones located in Layer 2 of the steel-steel composite are risk zones; however, they do not rule out the possibility of operating the reactor for quite a long period of time.

At the lower boundary of the weldability window, regularly distributed asperities rather than isolated ones are observed. In order to find the relief of the tantalum interface for the flat boundary, the following procedure was applied. Copper was etched out, and then SEM images of the tantalum interface at various angles to the beam were obtained. A SEM image of the interface is shown in Fig. 3a for one set of typical angles (tilt angle and rotation angle). 
Let us consider now an essential feature of the asperities the repeatability of self-similar elements of the relief (Fig. 3b). Even though the interface is considered to be flat, the asperities, however, look like wave splashes. This similarity is amazing, considering that the asperities have been generated from the solid phase that was not melted.

The transition to the area located slightly above the lower boundary of the weldability window can cause a transformation of the interface into the quasi-wavy and heterogeneous form. It consists of non-oriented areas, each of them having its own wave parameters (wave length and amplitude). Also note that, apart from the wavy interface, the splashes are observed occasionally and are indicated by arrows in Fig. 3c, d, e.

The quasi-wavy interface mostly resembles a patchwork quilt consisting of some pieces that have their own wave directions and splashes along interfaces. Such an uncommon interface has never been observed before. Unlike a perfect wavy interface, the quasi-wavy interface is unstable.

Within long operation periods of a chemical reactor, under a strong impact caused by movements of some aggressive media at rather high temperatures as well as by vibrations of the reactor shell, welded joints on the quasiwavy interface may lose their stability and, consequently, their uniformity.

\subsection{Petrochemical Reactor (Coke Drum)}

The $08 \mathrm{Cr} 13$ steel $-12 \mathrm{CrMo}$ steel two-layered composite plates made by explosive welding were joined by arc welding into the final construction of a coke drum.

The principal results of the examination of the explosive weld joint were obtained by SEM and are presented in Figs. $4 \mathrm{a}, \mathrm{b}$.

In [11] it turned out that the contact zone structure of the weld joint is fairly complex and is made up of a number of layers. Five layers of a different character are clearly seen. These layers and the transitions between them will be discussed further on. For convenience, the layers have been numbered.

In Fig. 4a a sequence of four layers is shown: 1: the steel $12 \mathrm{CrMo}$ recrystallized area; 2 : the steel $12 \mathrm{CrMo}$ local melted area; 3: the area of rod-shaped carbides in steel $08 \mathrm{Cr} 13$; 4: the area of randomly located carbides (probably of a different structure) in steel $08 \mathrm{Cr} 13$. There is a sharp interface between areas 3,2 and 1, that contrasts to the blurred interface between areas 3 and 4 . Layer 5 of the recrystallized steel 08Cr13 completes the sequence of layers (not shown in the Figure). Area 4 of the randomly distributed carbides in steel $08 \mathrm{Cr} 13$ is adjacent to area 3.

As is seen in Fig. 4a, local melting area 2 is adjacent to area 1 . The SEM chemical analysis proves that such a solidified melt is made up of chromium enriched and carbon depleted steel $12 \mathrm{CrMo}$. Numerous measurements reveal that the melt is characterized by randomly distributed inhomogeneities of chrome concentration. As is seen in Figs. 4a, area 2 borders on area 3 with a markedly higher carbide density. Area 3 is located along the edge of steel $08 \mathrm{Cr} 13$. A sharp boundary can be seen between areas 2 and 3. Colonies of rod-shaped carbides in area 3 are displayed in Fig. 4b.
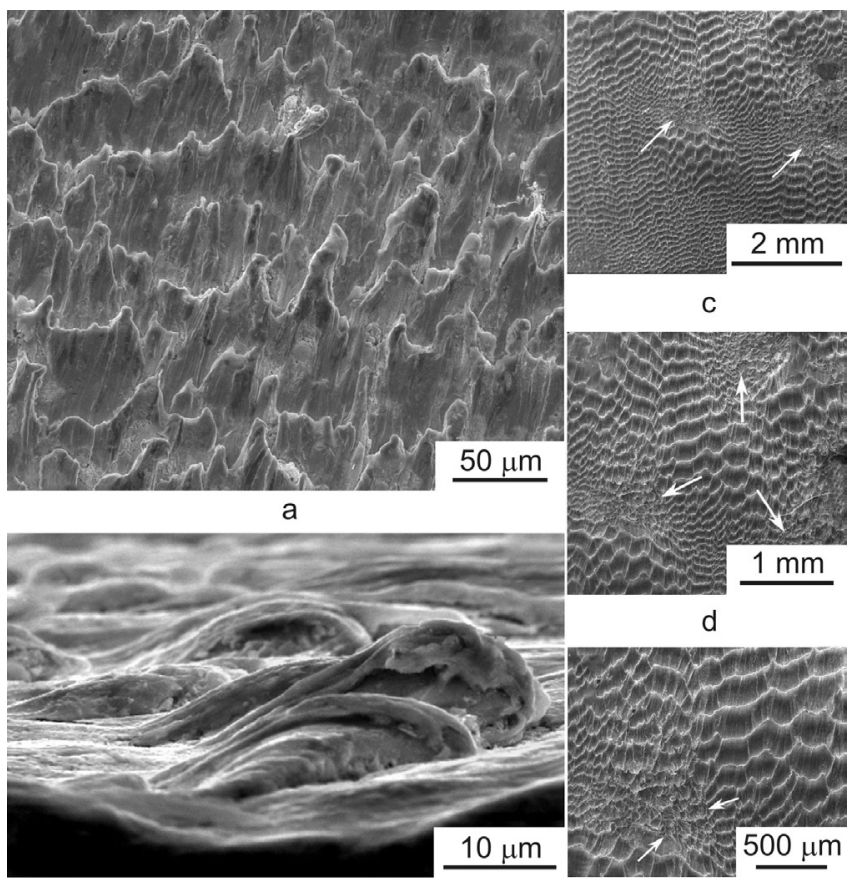

b

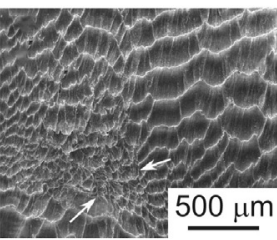

e

Fig 3. The structure of the tantalum surface (after etching out copper): splashes (a); interface element (b); quasi-wave interface at various magnifications $(c, d, e)$.

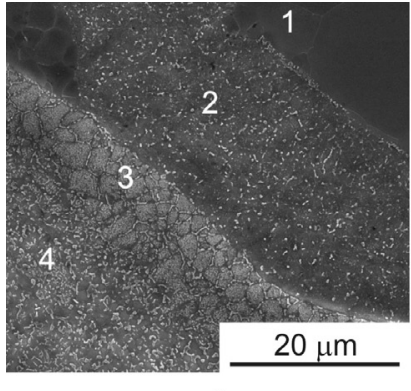

a

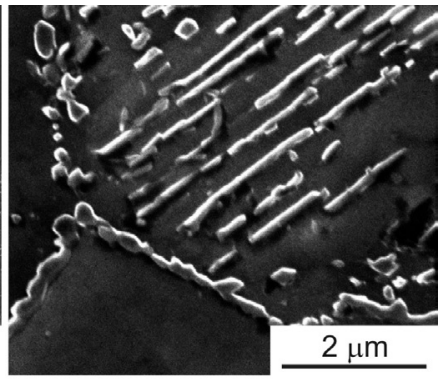

Fig. 4. Multilayered structure of steel $08 \mathrm{Cr} 13$ - steel $12 \mathrm{CrMo}$ joint: transitions between zones (a); area 3, containing a colony of rodshaped carbides (b).

Fig. $4 \mathrm{~b}$ displays a colony constituted of thin rod-shaped carbides of various lengths, predominantly of the same orientation. Some of them are located so close to each other that they practically merge; the others are widely separated from each other. The cross-sections of the rods are irregular polygons, which suggests that the rods have been facetted. As is shown in Fig. 4b, the rod thickness varies from 40 to $60 \mathrm{~nm}$.

Microhardness measurements in various bands of the transition zone indicate that the microhardness of the rodshaped carbide zone (area 3 in Fig. 4a) reaches the value of $3600 \mathrm{MPa}$ which exceeds the microhardness of recrystallized steel by approximately $2000 \mathrm{MPa}$ (areas 1 and 5). The high microhardness value is related not only to the microhardness of carbide but also to the fact that the carbides are arranged in colonies.

Further on, we will establish the reason for why such a high density of rod-shaped carbides is possible in area 3; in addition, the reason for why a high carbon concentration, which is required for the high carbide density, becomes possible for chrome steel, will be found. 
As a result of the high diffusion mobility of carbon in liquid, as it was reported in [12], carbon atoms start to flow in the direction from the melt to the solid phase. In the present case it is the flow from area 2 of steel 12CrMo to area 3 of steel $08 \mathrm{Cr} 13$. The carbon concentration in area 3 could be expected to attain the average concentration in steel $12 \mathrm{CrMo}$.

Somehow the situation turned out to be more complicated: carbon segregation starts at the melt and chrome steel interface, i.e. in the area where carbon concentration is increased compared to that of both steels. This fact is also supported in [13]. The segregation phenomenon has been known for a long time. There exist numerous studies of segregation in a wide variety of subjects: grain boundaries, domains, interface boundaries. Segregation in explosive welding at the melt and solid phase interface has been observed for the first time.

In case of the joint under study we are dealing with the bonding of high concentrations of chrome and carbon into carbides which have the shape of plates and rods and are grouped into colonies. Thus the advance of the interface is accompanied with eutectoid decomposition as was reported in [14] with the formation of carbide colonies and a depleted zone as was presented in [15].

The reactor walls during operation undergo pressure as a result of mixing of heavy oil fractions. In this situation the rod-shaped carbide colonies act as barriers which break dislocation glide in the plane transversal to the colony. Since the inclusions are shaped like rods, such mechanism as the climb of dislocations over obstacles is practically excluded. The mechanism of cutting inclusions with dislocations might be possible for isolated inclusions. However, this mechanism is extremely complicated in case of a colony: it is as if the dislocation gets into a "labyrinth" and cannot get out of it. Consequently, stress concentrators initiating the cracks expansion emerge.

As a result, the segregation zone containing rod-shaped carbide colonies is a risk zone for the petrochemical reactor wall. Three types of carbides were observed in the segregation zone. Cementite $(\mathrm{Fe}, \mathrm{Cr})_{3} \mathrm{C}$, enriched with chromium, was observed along the grain boundaries. The grains were formed by ferrite $(\alpha-\mathrm{Fe})$ with special carbides $(\mathrm{Fe}, \mathrm{Cr})_{23} \mathrm{C}_{6}$ and $(\mathrm{Fe}, \mathrm{Cr})_{7} \mathrm{C}_{3}$ in them. In fact, there are two risk zones because the segregation zone formation is conditioned by carbon transportation from the local melted zone. Hence, both the melted zone and the segregation zone turned out to be risk zones.

Based on the analysis above we believe that the choice of the heat treatment mode (annealing at $680-700^{\circ} \mathrm{C}$ within approximately two hours) was not the right one. Its parameters (temperature, duration) proved to be the ones that may support eutectoid decomposition.

The original specimen (as welded) was heated at $500^{\circ} \mathrm{C}$ for 2 hours and 10 hours. The melted zone that emerged during the welding was detected. Nevertheless, the rodshaped carbides were not observed in the adjoining chrome steel zone. Recrystallization occurs in the melted zone during the prolonged annealing. Hence, in order to avoid eutectoid decomposition, it is preferable to conduct heat treatment at the temperature of approximately $500^{\circ} \mathrm{C}$ to provide the removal of residual stresses through the prolonged annealing.

\subsection{Intermetallics Formation}

Due to the mutual solubility of the base elements, the formation of intermetallics upon explosive welding is possible. The authors of [16] studied joints of metals that had sufficiently high mutual solubility. The formation of intermetallics upon explosive welding of copper and titanium was studied in [17]. According to the study, the following phases have been identified: the metastable $\mathrm{Cu}_{3} \mathrm{Ti}$ and equilibrium $\mathrm{Cu}_{4} \mathrm{Ti}$. Multiple local melted zones were observed in the process. The work mentioned above contains the detailed description of the microheterogeneous structure of the local melted zones including the observation of the particles of clusters and intermetallic compounds inside the zones but without any relations between them. Here we give a direct proof of the transformation of smooth cluster particles into faceted intermetallics.

A SEM microscope heating adapter was used to heat the specimen of the two-layer copper-titanium composite and to record the video of the alteration of its structure. Several snapshots are presented in Fig. 5. First, mainly unfaceted cluster particles are observed (Figs. 5a), then the individual faceted intermetallics can be seen; further, they grow and the individual particles bond together. Figs. 5b, c exhibit the way the initially spherical particle, with an increase in heating time (indicated at every picture), acquires a facet, elongates and
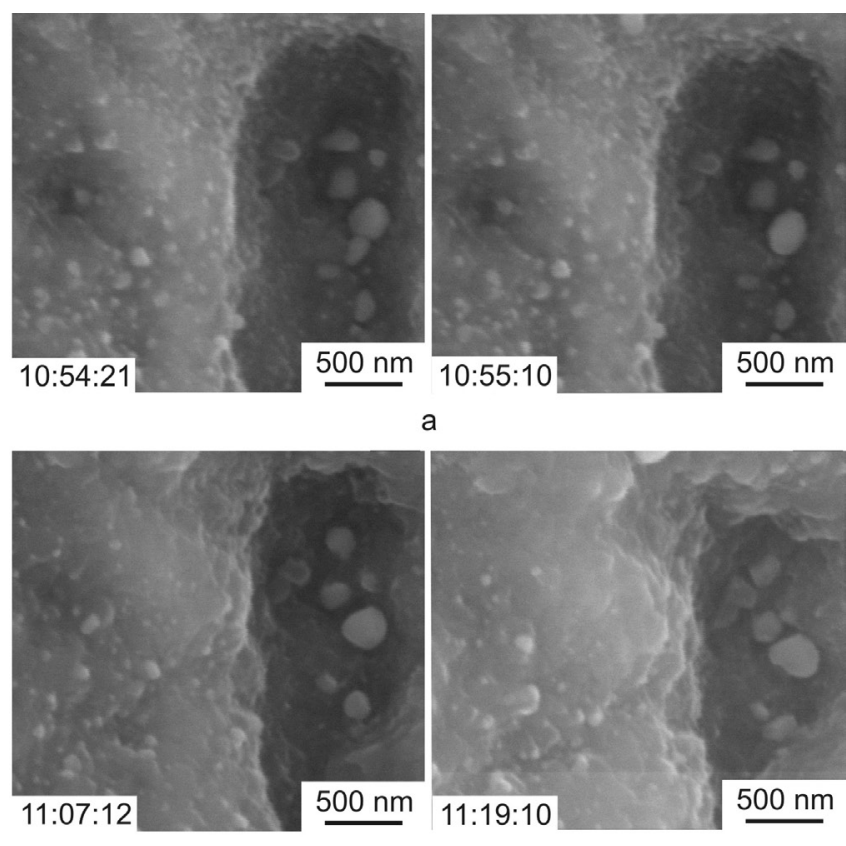

$\mathrm{b}$

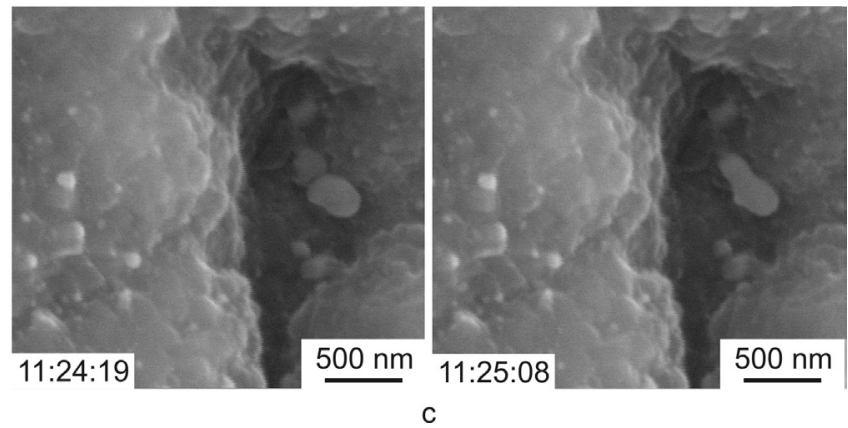

Fig. 5. Particle shape alteration upon heating $\left(700^{\circ} \mathrm{C}\right)$ in situ. 
becomes different from the initial one. Moreover, the particle convergence leading to the pick-up of smaller particles by larger ones can be observed.

In conclusion it should be noted that as per the current views intermetallic formation in explosive welding can be hazardous for a joint strength. Indeed, a bulk intermetallic specimen is brittle. On the other hand, inclusions of the solidified melt with intermetallic particles are used to strengthen, for example, steel grades and other materials. We believe that such particles only become hazardous in certain cases, in particular when intensifying a welding mode. As this takes place, the dynamics of the whole of intermetallic inclusions can be presented as follows: at the beginning the individual particles grow bigger and then merge into agglomerates. In the process the smaller particles are picked up by bigger ones. This process, as applied to recrystallization, was figuratively called "cannibalism" in [18].

The process is initiated when one surface emerges instead of two. Somehow the crystal lattices are randomly oriented, so they may misfit when joining each other; as a result the surface energy increases. The similar process of powder particle bonding results in powder consolidation under such a strong action as torsion under pressure as reported in [19].

Since the process resulting in particle adhesion is rather common, there always exists a possibility of joint failure conditioned by intermetallic brittleness in various modes of welding and under various subsequent operation conditions (loading, heating).

\section{Conclusions}

1. The reasons for the high quality of the chemical reactor wall containing the copper-tantalum welded joint were revealed. However a risk zone might occur due to the quasiwave nature of the interface.

2. The contact zone of the composite plates for the shell of the petrochemical reactor (coke drum) made by explosive welding and made of steel $08 \mathrm{Cr} 13$ and steel $12 \mathrm{CrMo}$ consists of five layers. The segregation provokes the eutectoid decomposition that causes the formation of colonies of rodshaped carbides. As a result, there are two risk zones: the melted zone and the segregation zone.

3. Using the copper-titanium joints as examples, the effect of intermetallic reactions on welded joint strength was studied. Disordered and unfaceted clusters were observed to turn into intermetallic particles. After that, intermetallic particles combined into agglomerates. The variety of modes and operation conditions makes the hazard of intermetallic formation quite real.

Electron-microscopic investigations were performed at the Electron Microscopy Center of Collaborative Access, Ural Branch, Russian Academy of Sciences.

Acknowledgments. The work was performed under the State Task (theme "Pressure" no. AAAA-A18-118020190104-3), project № 18-10-2-24, Program of Ural Branch, RAS and was supported in part by the Russian Foundation for Basic Research, project no. № 17-02-00025).

\section{References}

1. A. A. Deribas. High Pressure Research, 1, 365 (1989). DOI: $10.1080 / 08957958908202499$

2. J.F. Lancaster. Metallurgy of welding, 6th ed. Abington Pub, Abington Cambridge (1999) 468 p.

3. V.I. Lysak, S.V. Kuzmin. Explosion Welding. Moscow, Mashinostroenie (2005) 544 p. (in Russian) [Лысак В.И., Кузьмин С. В. Сварка взрывом. Москва, Машиностроение (2005) 544 с.]

4. V.V. Rybin, B.A. Greenberg, M.A. Ivanov, A.M. Patselov, O.V. Antonova, O.A. Elkina, A.V. Inozemtsev, G.A. Salishchev. Journal of Nanoscience and Nanotechnology, 11, 8885 (2011). DOI: 10.1166/jnn.2011.3513

5. D. Frey, J. Banker. Recent Successes in Tantalum Clad Pressure Vessel Manufacture: A New Generation of Tantalum Clad Vessels, Corrosion Solutions Conference. Wah Chang, USA (2003) P. 163 - 169.

6. B. A. Greenberg, M. A. Ivanov, V. V. Rybin, O. A. Elkina, O.V. Antonova, A.M. Patselov, A.V. Inozemtsev, A.V. Plotnikov, A.Y. Volkova, Y.P. Besshaposhnikov. Materials Characterization. 75, 51 (2013).

7. B.A. Greenberg, M.A. Ivanov, A. V. Inozemtsev, A.M. Patselov, M.S. Pushkin, A.M. Vlasova. Metall and Mat Trans A. 46, 3569 (2015). DOI: $10.1007 /$ s11661-015-2968-3

8. K.S. Birdi. Handbook of surface and colloid chemistry. CRC Press/Taylor and Francis, Boca Raton (2009) 709 p.

9. D. Grady. Fragmentation of Rings and Shells: The Legacy of N. F. Mott. Springer, Berlin Heidelberg (2006) 373 p.

10. A. V. Pocius. Adhesion and adhesives technology: an introduction, 2d ed. Hanser Publishers, Hanser/Gardner Publications, Munich, Cincinnati (2002) 352 p.

11. B.A. Greenberg, O.A. Elkina, A.M. Patselov, A. V. Plotnikov, M. A. Ivanov, Y.P. Besshaposhnikov. Journal of Materials Processing Technology. 215, 79 (2015). DOI: 10.1016/j.jmatprotec.2014.08.008

12. F. Ernst, A. Avishai, H. Kahn, X. Gu, G. M. Michal, A. H. Heuer. Metall and Mat Trans A. 40, 1768 (2009). DOI: $10.1007 /$ s11661-009-9854-9

13. J. Cermak, L. Kral. Journal of Alloys and Compounds. 586, 129 (2014). DOI: 10.1016/j.jallcom.2013.10.058

14. R. Elliott. Eutectic solidification processing: crystalline and glassy alloys. Butterworths, London, Boston (1983) $378 \mathrm{p}$.

15. E. Houdremont. Handbuch der Sonderstahlkunde, 3-d ed. Springer-Verlag, Berlin Heidelberg (1956) 1051 p.

16. B.A. Greenberg, M.S. Pushkin, A.M. Patselov, A.M. Inozemtsev, M.A. Ivanov, O.V. Slautin, Yu. P. Besshaposhnikov. Welding International. 31(5), 384 (2017). DOI: 10.1080/09507116.2016.1263462

17. B.A. Greenberg, M.A. Ivanov, M.S. Pushkin, A. V. Inozemtsev, A.M. Patselov, A.P. Tankeyev, S. V. Kuzmin, V.I. Lysak. Metall and Mat Trans A. 47, 5461 (2016). DOI: 10.1007/s11661-016-3729-7

18. R.W. Cahn, P. Haasen. Physical Metallurgy. Elsevier Science (1996) 2960 p.

19. A. P.Zhilyaev, T. G.Langdon. Progress in Materials Science. 53, 893 (2008). DOI: 10.1016/j.pmatsci.2008.03.002 